\title{
An Experimental Study on the Effect of Microstructure on Wear Behavior of Fe-Cr-C Hardfacing Alloys
}

\author{
K.M. KenchiReddy and C.T. Jayadeva
}

\begin{abstract}
Hardfacing is a low cost method of depositing wear resistant surfaces on metal components to extend service life. The prime requirement of a metal is to have good resistance to wear, corrosion and high temperature. A study has been carried out to investigate the relationship between abrasive wear resistance and microstructure of $\mathrm{Fe}-\mathrm{Cr}-\mathrm{C}$ hardfacing alloy. Two different commercial hardfacing electrodes were employed to investigate the effect of the microstructure. Results indicate that as hardness increases, the loss of wear decreases. Electrode-I has less wear as compared to electrode-II as the percentage of chromium, carbon and silicon is more in electrode-I. The abrasion tests were carried out in a dry sand-rubber wheel abrasion machine according to the procedure A of ASTM G65 standard. The factors such as, arc current, arc voltage, welding speed, electrode stick-out and preheat temperature, predominantly influence the weld quality.
\end{abstract}

Keywords--- Hardfacing, Welding, Microstructure, Wear Resistance, Alloys

\section{INTRODUCTION}

$\mathrm{H}$ ARDFACING is a low cost method of depositing wear resistant surfaces on metal components to extend service life [1]. A wide variety of hardfacing alloys are commercially available for protection against wear and selecting the best suited for a particular application is very essential. The composition of the deposit will depend upon the base metal composition and dilution. Base metal composition is very significant in determining the preheating temperature. Carbon and low-alloy steels with carbon content of less than one percent can be easily hardfaced whereas high-carbon steel may require a special buffer layer.

Selection of an alloy also depends on the nature of the service creating the need for hardfacing. Various surface alloys are available in different forms such as, bare welding

K.M. Kenchi Reddy, Research Scholar, Department of Mechanical Engineering, Dr. T. Thimmaiah Institute of Technology, KGF, India. Email:kenreddy@rediffmail.com

C.T. Jayadeva, Professor, Department of Mechanical Engineering, Adichunchanagiri Institute of Technology, Chikmagalur, India. E-mail: ctjayadeva@yahoo.co.in rods, electrodes, and coiled wires and also in the form of powders. It serves satisfactorily in certain conditions depending upon its composition, microstructure of the deposited layer and its hardness. Fe-Cr-C alloys are used in severe conditions where there is extreme erosion and therefore abrasion resistance is necessary.

Their exceptional abrasive and erosive wear resistance results primarily from their high volume fraction of hard carbides, though the toughness of the matrix also contributes to the wear resistance.

The hardfacing alloys obtained using high-energy density sources such as electron beam welding; plasma arc and laser have been widely applied to enhance the wear and corrosion resistance of material surface [2]. In this context, the present investigation has been initiated to identify the most suitable hardfacing deposits from among two commercial electrodes and the effect of welding on the wear behaviour of hardfacing deposits.

\section{LiTERATURE REVIEW}

Hardfacing is one of the most economical and most widely used methods of improving surface characteristics without changing the bulk properties of components [3]. Fe-Cr-C alloys are well known for their excellent performances under severe wear conditions [4], [5].

$\mathrm{Fe}-\mathrm{Cr}-\mathrm{C}$ base hardfacing deposits are typically applied to a wide variety of top surfaces and preparation of such hardfacing deposits requires the choice of the welding consumables and a welding procedure [6]. A wide variety of hardfacing alloys are commercially available for protection against wear [7]. Deposits with a microstructure composed by disperse carbides in austenite matrix are extensively used for abrasion applications and are typically classified according to the expected hardness [8]. Nevertheless, the abrasion resistance of a hardfacing alloy depends on many other factors such as the type, shape and distribution of hard phases, as well as the toughness and strain hardening behavior of the matrix [9]. Chromium-rich electrodes are widely used due to low cost and availability; however, more expensive tungsten or vanadium-rich alloys offer better performance due to a good combination of hardness and toughness. Complex carbides electrodes are also used; especially when abrasive wear is accompanied by other wear mechanisms [10]. 
Table 1: Chemical Composition of Base Metal (In Weight Percentages)

\begin{tabular}{|c|c|c|c|c|}
\hline $\mathrm{C}$ & $\mathrm{Si}$ & $\mathrm{Mn}$ & $\mathrm{S}$ & $\mathrm{p}$ \\
\hline 0.18 & 1.47 & 0.32 & 0.013 & 0.029 \\
\hline
\end{tabular}

Table 2: Chemical Composition of Hardfacing Alloy (In Weight Percentages)

\begin{tabular}{|c|c|c|c|c|c|c|c|c|c|}
\hline Electrode & $\mathrm{C}$ & $\mathrm{Si}$ & $\mathrm{Mn}$ & $\mathrm{S}$ & $\mathrm{p}$ & $\mathrm{Cr}$ & $\mathrm{Mo}$ & $\mathrm{Ni}$ & $\mathrm{V}$ \\
\hline Hardfacing 1 & 0.33 & 0.28 & 1.15 & 0.014 & 0.025 & 2.22 & - & - & - \\
\hline Hardfacing 2 & 0.1 & 0.38 & 1.51 & 0.024 & 0.03 & 2.15 & 0.745 & 1.09 & 0.103 \\
\hline
\end{tabular}

Several welding techniques such as oxyacetylene gas welding (OAW), gas metal arc welding (GMAW), shielded metal arc welding (SMAW) and submerged arc welding (SAW) can be used for hardfacing. The most important differences among these techniques lie in the welding efficiency, the weld plate dilution and the manufacturing cost of welding consumables [11].

In this study two different hardfacing alloys were used for overlaying. These are basically iron based alloys having varying amount of chromium, carbon and other alloying elements as they are more suitable for low stress abrasive wear conditions [12], [13], [14].

\section{EXPERIMENTAL DETAILS}

\section{A. Base Metal}

The selection of base metal is very essential in deciding what alloy to use for hardfacing deposit. Since welding procedure differs according to the base metal. The base metal selected for this study is mild steel which composes the main elements of carbon, silicon, manganese, sulphur, and phosphorous. The chemical composition is shown in Table 1.

\section{B. Hardfacing Alloys}

Two different commercial hardfacing alloys were used for overlaying. These alloys were selected due to its low cost and easy availability in the local market and suitability for the service condition (low stress abrasion). They are basically iron - based alloys having varying amount of chromium, carbon, silicon and other alloying elements as they are more suitable for shielded metal arc welding process. Chemical compositions of two electrodes are presented in Table 2.

\section{Welding Conditions}

The standard size test specimens of 16 nos. with the dimensions of $250 \times 100 \times 12 \mathrm{~mm}$ were selected for the experiment. The following precautions are taken before hardfacing.

- The electrodes are perfectly dried in the furnace and baked at $250^{\circ} \mathrm{C}$ one hour before the use

- Area of the weld is properly cleaned

- Preheated the hardfacing area to a minimum of $200^{\circ}$ C

\section{Methodology}

The experiment was carried out in three stages to investigate the effect of current, travel speed and voltage on hardfacing electrodes, and the corresponding hardness was determined.

i. In first stage, voltage (V) and travel speed (S) were kept constant and current (A) was increased.

ii. In second stage, voltage (V) and current (A) were kept constant and travel speed (S) was increased.

iii. In third stage, current (A) and travel speed (S) were

iv. kept constant and voltage (V) was increased

The selected standard size of the test specimen is shown in figure 1 . The results of hardfacing obtained by varying current, travel speed and voltage along with their hardness and the corresponding relationship between them is shown in figures 2, 3 and 4 respectively. 


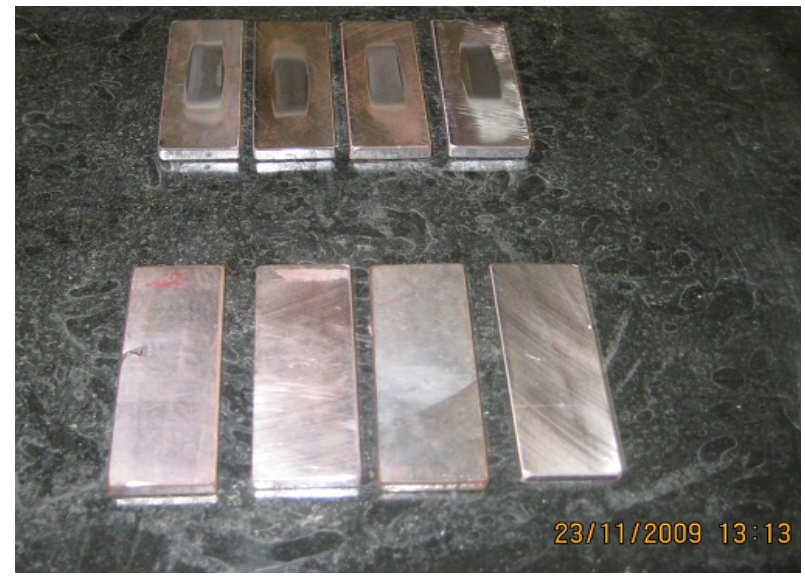

Figure 1: Standard Test Specimen of Size $75 \times 26 \times 6 \mathrm{~mm}$

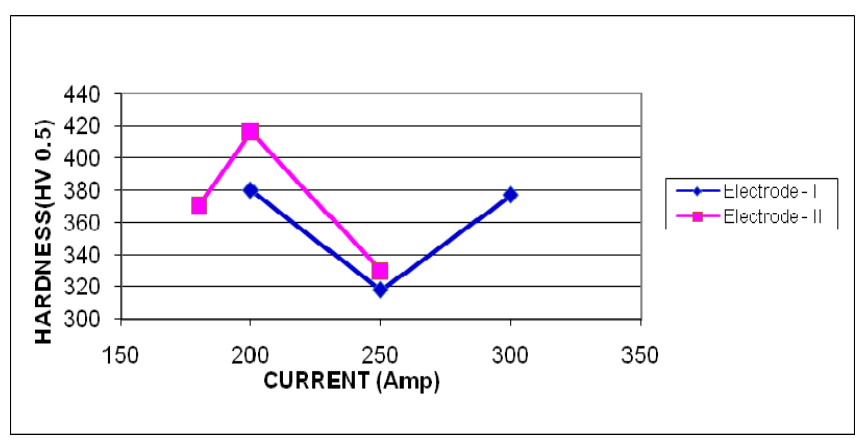

Figure 2: Hardness vs Current

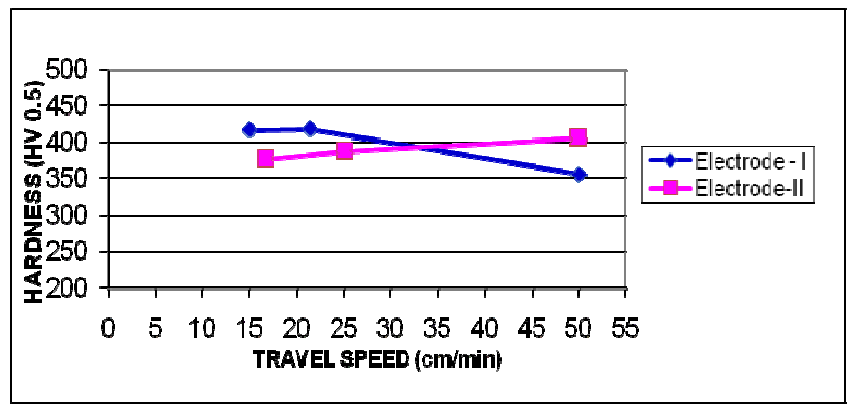

Figure 3: Hardness vs Speed

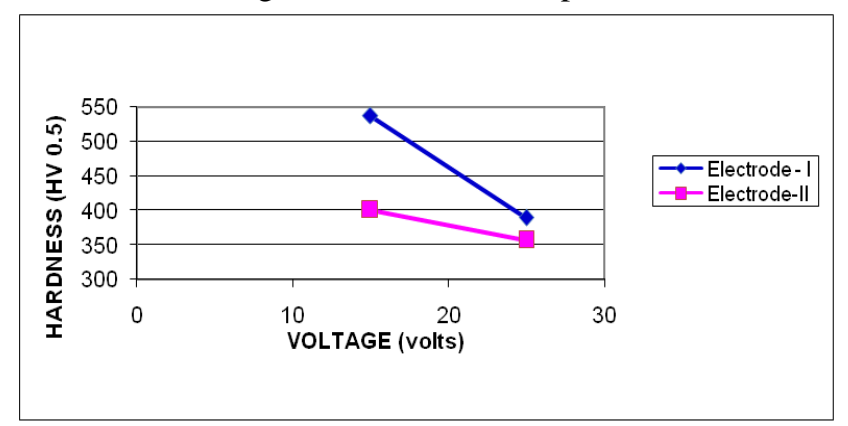

Figure 4: Hardness vs Voltage

\section{RESUlTS AND DiscUSSION}

\section{A. Hardness Test}

The specimens were cut to a size of $100 \times 30 \times 12 \mathrm{~mm}$ for hardness testing and were polished using standard metallographic procedure. Micro hardness surveys were made on these specimens using Vickers hardness tester along the direction of thickness from the top surface towards the base metal after every $0.5 \mathrm{~mm}$. These surface values are plotted in the form of a graph shown in figure 5 .

The hardness survey of heat affected zone (HAZ) samples for every $0.5 \mathrm{~mm}$ depth was made. The results indicate that the hardness values are more on the weld surface \& decrease towards the base metal \& remain constant on the base metal.

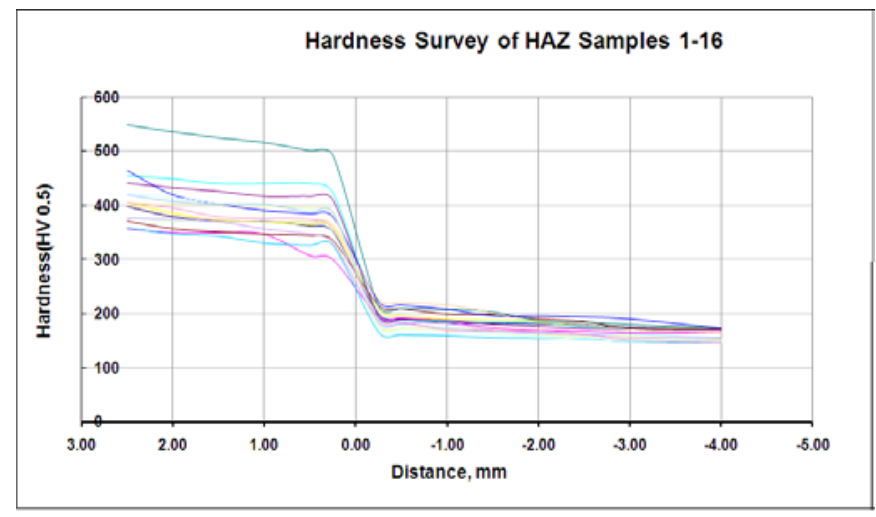

Figure 5: Hardness Survey of HAZ

\section{B. Dry Sand Abrasive Wear Test}

Sample of $26 \times 75 \times 6 \mathrm{~mm}$ size were used for analysis. Specimens were ground using surface grinder to make the surface flat. Dry sand abrasive wear test was carried out as per ASTM G65 standards. In this test, samples were held against a rotating rubber wheel under the constant flow of abrasives in between the sample and the rubber wheel under predetermined load. The test conditions are given here under:

Speed: $200 \pm 5 \mathrm{rpm}$

Sample run duration: 30 minutes

Silica sand of size between 200 to $250 \mu \mathrm{m}$ was used as abrasive. Load is kept constant at $130.5 \mathrm{~N}$ for all the specimens. The wear rate was calculated as weight loss in gms. Results indicate that as hardness increases, the loss of wear decreases. Electrode-I has less wear as compared to electrode-II as the percentage of chromium, carbon and silicon is more in electrode-I. However the composition of chromium, carbon \& silicon in the weld deposit made with type-I electrode is higher than that of weld deposit made with type-II electrode. Higher amount of chromium, carbon, silicon and finer structure resulted in higher hardness where as lower hardness values were recorded in weld deposit with less amount of Cr, C \& Si \& coarser structure. From wear testing data under various conditions of the parameters, it can be stated that weld deposits made with type I electrode are more wear resistant than the weld deposits made with type II electrode.

\section{CONCLUSION}

Experimental investigation revealed that, weld metal 
chemistry \& hardness have significant influence on wear property. Wear resistance increases with increase in percentage of chromium \& carbon content in weld deposits and the hardness mainly depends on process parameters such as welding current, speed of arc travel and voltage. The analysis carried out on hardness survey of HAZ samples for every $0.5 \mathrm{~mm}$ depth indicates that the hardness values are more on the weld surface \& decrease towards the base metal \& remains constant on the base metal.

\section{REFERENCES}

[1] E.N. Gregory, Surfacing by welding, Weld. Inst. Res. Bull. 21 (1), Pp. 9-13, 1980.

[2] Lu L, H. Soda, A. McLean, Material Science Engineering, A 347, Pp. 214, 2003.

[3] M.H. Korkut, O. Yilmaz, S. Buytoz, "Effect of aging on the microstructure and toughness of the interface zone of a gas tungsten arc (GTA) synthesized Fe-Cr-Si-Mo-C coated low carbon steel”, Surf. Coat. Technol, 157, Pp.5-13, 2002.

[4] E. Badisch, M. Kirchgaßner, R. Polak, F. Franek, "The comparison of wear properties of different Fe-based hardfacing alloys in four kinds of testing methods", Triobotest 14, Pp. 225-233, 2008.

[5] M. Kirchgaßner, E. Badisch, F. Franek, "Behaviour of iron-based hardfacing alloys under abrasion and impact, Wear”, 265, Pp. 772-779, 2008.

[6] R.J. Dawson, S. Shewchk, J.E. Pritchard, "Selection and use of hardfacing alloys”, Weld, J. 61 (11), Pp. 15-23, 1982.

[7] M.F. Buchely, J.C. Gutierrez, L.M. Le'on, A. Toro, "The effect of microstructure on abrasive wear of hardfacing alloys, Wear”, 259, Pp. 52-61, 2005.

[8] C. Roda V'azquez, A. Loureiro, J. Pita Cribeiro, Comportamiento frente al desgaste abrasivo de las aleaciones con tendencia a la formaci'on de carburos aplicados por soldadura, Mantenimiento, 134, Pp. 78-89, 2000.

[9] S. Chatterjee, T.K. Pal, "Wear behavior of hardfacing deposits on cast iron, Wear”, 255, Pp. 417-425, 2003.

[10] S.-H. Choo, C.K. Kim, K. Euh, S. Lee, J.-Y. Jung, S. Ahn, "Correlation of microstructure with the wear resistance and fracture toughness of hardfacing alloys reinforced with complex carbides", Metall. Mater. Trans, A 31A, Pp. 3041-3052, 2000.

[11] W. Wo, L.-T. Wu, "The wear behavior between hardfacing materials", Metall. Mater. Trans. A 27A , Pp. 3639-3648, 1996.

[12] R Das Gupta,"Surface Engineering- An Avenue for Improving Life of Agricultural Implements”, IE (I) Journal-MM, Vol. 79, Pp. 36-43, 1998.

[13] L.P. Fominskii, "Hardfacing working components of agricultural machines using an electron accelerator", Welding International, Vol. 12, Pp. 1110-1113, 1998.

[14] D. J Kotecki and J. S, Ogborn, "Abrasion Resistance of Iron-Based Hardfacing Alloys”, Welding Journal, Pp. 269-278, 1995.

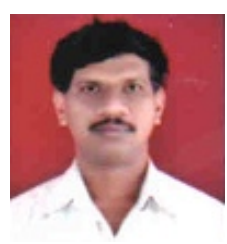

C. $\mathbf{T}$ Jayadeva is born in Karnataka, India on $18^{\text {th }}$ July 1963. He earned his Undergraduate degree in Industrial \& Production Engineering in 1986 from University of Mysore, Karnataka, Postgraduate degree in Industrial Engineering from university of Calicut, Kerala in the year 1993 and $\mathrm{Ph}, \mathrm{D}$ in Quality Management from VTU, Belgaum, India in the year 2008. He worked as Principal at Yagachi Institute of Technology, Hassan, Karnataka and presently working as Professor in the Department of Mechanical Engineering, AIT, Chikmaglur, Karnataka, He has published 19 papers in National/International conferences/journals. He is a Life Member of Indian Society for Technical Education.

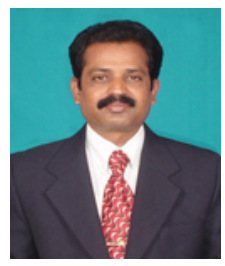

K. M. Kenchi Reddy is born in Karnataka, India on $4^{\text {th }}$ August 1961. He earned his Undergraduate degree in Mechanical Engineering in 1986 from University of Mysore, Karnataka, India, Postgraduate degree in Production Engineering and Technology from Mysore University in the year 1994 and presently working as
Assistant Professor in the Department of Mechanical Engineering, Dr T Thimmaiah Institute of Technology, KGF. He is a Life Member of Indian Society for Technical Education. 